\title{
Soil pH, exchangeable aluminium and legume yield responses to deep-placed lime at Omarama Station
}

\author{
D.L. HENDRIE ${ }^{1}$, J.L. MOIR ${ }^{1}$, E.J. STEVENS ${ }^{2}$, A.D. BLACK ${ }^{1}$ and D.J. MOOT ${ }^{1}$ \\ ${ }^{1}$ Faculty of Agriculture and Life Sciences, Lincoln University, \\ PO Box 85084, Lincoln 7647, Canterbury, New Zealand \\ ${ }^{2}$ Flexiseeder Ltd, Governors Bay Road, Lyttleton, New Zealand \\ jim.moir@lincoln.ac.nz
}

\begin{abstract}
The passive moment of lime down the soil profile in dryland is slow so a machine was developed to directly inject lime into soil, and was tested it at Omarama Station. Pelleted lime was injected at simultaneous depths of $5-10 \mathrm{~cm}$ and $20-25 \mathrm{~cm}$ below the soil surface at rates of 0 (control), 500, 1000, and $2000 \mathrm{~kg} / \mathrm{ha}$ and these treatments were compared with $1000 \mathrm{~kg} / \mathrm{ha}$ of surface-applied pelleted lime. The growth of lucerne, 'Russell' lupins and festulolium was recorded over 3 years. The deep-placed lime increased soil $\mathrm{pH}$ and reduced Al levels at soil depths of 25 and $30 \mathrm{~cm}$, whereas for the surface-applied lime this was only the case in the top $7.5 \mathrm{~cm}$ of the soil. The deep-placed lime increased the growth of lucerne in the second and third years of the experiment. The lucerne was out-yielded by 'Russell' lupins in each year, which were unaffected by the application of lime.
\end{abstract}

Keywords: aluminium toxicity, Festulolium branuii, injected lime, lime ripper, Lupinus polyphyllus, Medicago sativa.

\section{Introduction}

Toxic levels of exchangeable aluminium (Al) occur extensively in the acid soils of the South Island hill and high-country (Moir \& Moot 2014; Whitley et al. 2016). $\mathrm{Al}$ is particularly toxic to legumes which are relied upon in the hill and high-country for nitrogen fixation and quality feed (Scott 2003). Al toxicity impedes root growth, damages root caps and root hairs, inhibits nodulation and reduces the ability of plants to extract water and nutrients from soil (Foy et al. 1978). Al is prevalent in subsoil layers of hill and high-country soils (Whitley et al. 2016) which can limit the rooting depth of legumes.

$\mathrm{Al}$ is generally considered to become toxic to legumes at a level of $3.0 \mathrm{mg} / \mathrm{kg}$ soil $\left(0.02 \mathrm{M} \mathrm{CaCl}_{2}\right.$ extraction) (Edmeades et al. 1983). However, the susceptibility of different legumes to Al toxicity differs considerably (Moir et al. 2016). Lucerne (Medicago sativa) is a deep rooting and drought tolerant legume that produces high quality feed, but it is highly susceptible to $\mathrm{Al}$, and this restricts its use in South Island hill and high-country
(Moot \& Pollock 2014; Moir et al. 2016). Other legumes such as 'Russell' lupins (Lupinus polyphyllus) and Lotus pedunculatus are more tolerant of low $\mathrm{pH}$ and $\mathrm{Al}$ and have potential for use in the South Island hill and high-country (Scott 1989; Moot \& Pollock 2014; Moir et al. 2016).

Lime is required to reduce soil acidity and $\mathrm{Al}$ concentration before an $\mathrm{Al}$ sensitive crop, such as lucerne, can be successfully grown. However, passive movement of lime down the soil profile is slow, especially in dryland environments (Farina \& Channon 1988; Kirchhof et al. 1995; Moir \& Moot 2014). Conventionally, cultivating lime into soil is also undesirable in many hill and high-country soils due to the risk of wind erosion, soil stoniness, expense, and it has been shown to be ineffective at reducing soil acidity below the depth of cultivation (Farina \& Channon 1988; Coventry 1991).

To overcome this problem a prototype machine was developed to deep-place lime by injecting it into subsoil layers with minimal cultivation. The Flexiseeder ${ }^{\circledR}$ lime ripper pneumatically feeds lime from a hopper to two delivery ports behind each of the eight, height and angle adjustable, $30 \mathrm{~cm}$ spaced Kverneland ripper tines that are fixed to a custom built frame. Optimise ${ }^{\circledR}$ pelleted lime (CP Lime Solutions Ltd 2015) was used in this experiment due to its consistency of particle size for steady calibration of the machine.

The objective of this study was to determine if injecting lime into an acid subsoil can change the soil $\mathrm{pH}$ and allow aluminium sensitive species such as lucerne to be grown successfully. This was done at Omarama Station where the growth of lucerne and 'Russell' lupins was measured over three growing seasons between 2015 and 2018. Comprehensive sampling of the distribution and effects of the applied lime on plant roots, soil $\mathrm{pH}$ and $\mathrm{Al}$ was carried out in December 2016 and January 2018.

\section{Methods \\ Site description}

The experimental site $(\mathrm{OM})$ was located on the fluvial flats of Omarama Station south of the Omarama township on a Mackenzie shallow loam soil (S-Map 


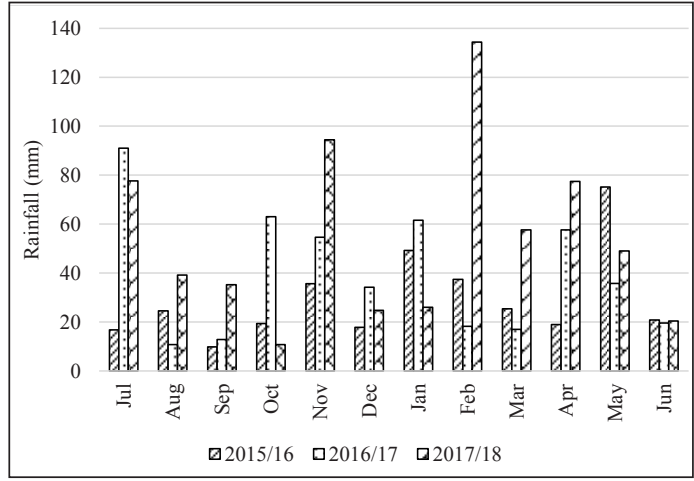

Figure 1 Monthly rainfall at the Omarama Station experimental site 2015-2018.

2015 ) at location $44^{\circ} 30^{\prime} 23.60^{\prime \prime} \mathrm{S} 169^{\circ} 54^{\prime} 16.04^{\prime \prime} \mathrm{E}$ and at $475 \mathrm{~m}$ a.s.l. Before the experiment the site had been in an undeveloped state, supporting mostly browntop (Agrostis capillaris), haresfoot clover (Trifolium arvense), and hawkweed (Pilosella officinarum). For a July to June production year, total rainfall recorded at the site for 2015/2016 was $351 \mathrm{~mm}$, with $472 \mathrm{~mm}$ for $2016 / 2017$ and $647 \mathrm{~mm}$ for $2017 / 2018$, with the monthly distribution shown in Figure 1.

Pre-treatment, the experimental site was extensively soil core sampled at $0-7.5 \mathrm{~cm}$ and $7.5-15 \mathrm{~cm}$ depths and the soil chemically analysed (Table 1 ).

\section{Experimental design}

The experiment was initially laid out in a randomised block design with each treatment replicated five times in $25 \times 12.5 \mathrm{~m}$ blocks, each separated by $6 \mathrm{~m}$. Firstly, ripping to a depth of $\sim 30 \mathrm{~cm}$, Optimise ${ }^{\circledR}$ pelleted lime $\left(90 \% \mathrm{CaCO}_{3}\right)$ was directly injected (May 2015) with the eight tine, $2.5 \mathrm{~m}$ wide ripper, simultaneously at soil depths of $5-10 \mathrm{~cm}$ and $20-25 \mathrm{~cm}$ in adjoining $25 \mathrm{~m}$ long strips. The lime was injected at rates of 0 (control), 500, 1000, and $2000 \mathrm{~kg} / \mathrm{ha}$, along with a separate treatment of 1000 $\mathrm{kg}$ /ha of surface-applied (SA) Optimise ${ }^{\circledR}$ lime. Following the lime application the site was heavy rolled and winterfallowed before being sown in November 2015.

The site was sown perpendicularly to the direction the lime was applied using two adjoining passes of a
$2.1 \mathrm{~m}$ wide Flexiseeder ${ }^{\circledR}$ plot drill to create $4.2 \times 2.5$ $\mathrm{m}$ plots. 'Force 4' lucerne, 'Russell' lupins, 'Perun' festulolium (Festulolium braunii) and two replicates of 'Rahu' ryecorn (Secale cereale)/block were sown at $14,12,25$ and $150 \mathrm{~kg}$ viable seed/ha, respectively. The ryecorn was sown as a break-in crop (Anderson et al. 2014) and subsequently resown with a second rotation of lucerne and 'Russell' lupins at the beginning of the second year of the experiment (October 2016). Urea was spread on all plots at $40 \mathrm{~kg} / \mathrm{ha}$ at sowing to assist with the early stages of plant establishment.

In October 2016, at the beginning of the second year of the experiment, the plant treatment strips were halved and overlaid with a low $(100 \mathrm{~kg} / \mathrm{ha})$ or high $(400$ $\mathrm{kg} / \mathrm{ha}$ ) rate of 'Sulphur super 30' (0-7-0-30) fertiliser to create a split-plot experimental design with $2.1 \times 2.5$ m subplots.

\section{Measurements}

Herbage yield measurements were carried out three times in the first production year $(2015 / 2016)$, once in the spring of the second year (2016/2017) and in the spring and autumn of the third year (2017/2018), with an additional lucerne measurement during that summer. The measurement in the second year was of main plots only. After each harvest all plots were mown to a height of 5-10 cm with a sickle bar mower. Sampled herbage had any weeds removed before drying at $65^{\circ} \mathrm{C}$ for 48 hours to determine dry matter content and yield.

To investigate the effects of the deep-placed and surface-applied lime treatments on soil $\mathrm{pH}, \mathrm{Al}$ and root architecture, $40 \mathrm{~cm}$ wide by $50 \mathrm{~cm}$ deep trenches were dug with a mini-excavator at the boundaries of the lucerne and 'Russell' lupin plots, in December 2016. From each plot all of the roots contained within a $1 \mathrm{~m}$ transect were carefully extracted from one drill row adjacent to the edge of the trench. These transects were positioned randomly relative to the location of the $30 \mathrm{~cm}$ spaced rip lines. This sampling occurred again in January 2018 when all lucerne plots were sampled but 'Russell' lupins were only sampled from Blocks 1,3 , and 5. The collected root samples were washed and roots of all 'Russell' lupin plants and 10 randomly selected lucerne plants from each sample were

Table 1 Soil test results for the OM experimental site, March 2015.

\begin{tabular}{|c|c|c|c|c|c|c|c|c|c|c|}
\hline $\begin{array}{l}\text { Depth } \\
(\mathrm{cm})\end{array}$ & $\mathrm{pH}^{\mathrm{a}}$ & $\begin{array}{c}\text { Exch. Alb } \\
(\mathrm{mg} / \mathrm{kg})\end{array}$ & $\begin{array}{l}\text { Olsen P } \\
(\mu \mathrm{g} / \mathrm{ml})\end{array}$ & $\begin{array}{c}\text { ASC }^{a} \\
(\%)\end{array}$ & $\begin{array}{l}\mathbf{S O}_{4}-\mathbf{S}^{\mathbf{c}} \\
(\mu \mathrm{g} / \mathrm{g})(\end{array}$ & $\begin{array}{c}\text { Org-Sc } \\
\mu \mathrm{g} / \mathrm{g})\end{array}$ & $\begin{array}{c}\text { CEC } \\
(\mathrm{me} / 100 \mathrm{~g})\end{array}$ & $\begin{array}{l}\text { BS } \\
\text { (\%) }\end{array}$ & $\begin{array}{c}\text { C } \\
(\%)\end{array}$ & $\begin{array}{c}\mathrm{N} \\
(\%)\end{array}$ \\
\hline $0-7.5$ & 5.3 & 4.5 & 16 & 19 & 7 & 4 & 10 & 37 & 2.89 & 0.24 \\
\hline $7.5-15$ & 5.0 & 8.0 & & & & & & & & \\
\hline
\end{tabular}


measured for length and scored for nodulation on a 0 (no nodules) to 5 (heavily nodulated) scale and for branching on a 1 (singular taproot) to 5 (highly branched) scale. The samples were then cut into $0-30 \mathrm{~cm}$ and $>30 \mathrm{~cm}$ depth sections and dried at $65^{\circ} \mathrm{C}$ for 48 hours to determine root dry matter biomass.

Following the root extraction, the walls of the trenches were squared off and a modified $7.5 \mathrm{~cm}$ deep soil corer was used to take core samples horizontally into the exposed soil along a $1 \mathrm{~m}$ transect. In December 2016, 11 individual soil cores were taken every 10 $\mathrm{cm}$ along the $1 \mathrm{~m}$ transect from each of the lucerne plots in Blocks 1, 3 and 5 at soil depths of 10 and 20 $\mathrm{cm}$ (Figure 2). These were individually analysed for $\mathrm{pH}$ and $\mathrm{Al}$ to assess the lateral spread of the deepplaced lime within the $1 \mathrm{~m}$ transect. These transects were directly in line with where the root sampling had occurred. In January 2018 all lucerne plots were again sampled with six 20 $\mathrm{cm}$ spaced core samples taken along the $1 \mathrm{~m}$ transect, these core samples were bulked to investigate the cumulative effect of the deep-placed lime across the $1 \mathrm{~m}$ transect at sampling depths of $10,15,20,25$, and $30 \mathrm{~cm}$ below the soil surface. These were analysed for $\mathrm{pH}$ and $\mathrm{Al}$ (Figure 3). Core samples (7.5 $\mathrm{cm}$ deep) were also taken across the surface of the plots.

Before analysis the soil samples were air-dried at $30^{\circ} \mathrm{C}$ for one week and $2 \mathrm{~mm}$ sieved. Soil $\mathrm{pH}$ was measured by mixing $10 \mathrm{~g}$ of soil in $25 \mathrm{ml}$ de-ionised water (Blakemore et al. 1987) and $\mathrm{Al}$ by extracting 5 g soil with $10 \mathrm{ml} 0.02 \mathrm{M} \mathrm{CaCl}_{2}$, followed by ICP-OES analysis. 2016.

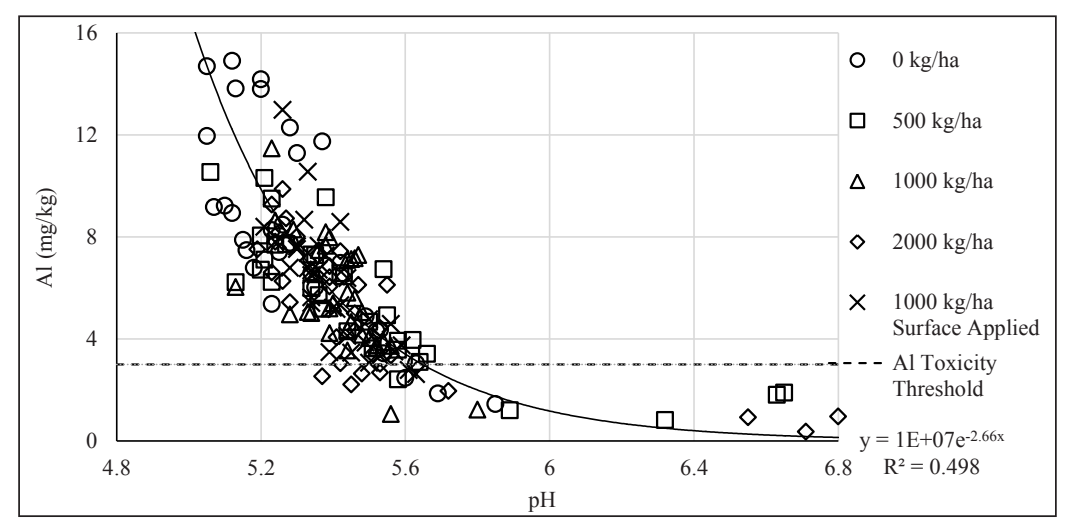

Figure 2 Lime treatment effects on soil $\mathrm{pH}$ and $\mathrm{Al}$ concentration at $20 \mathrm{~cm}$ depth, December

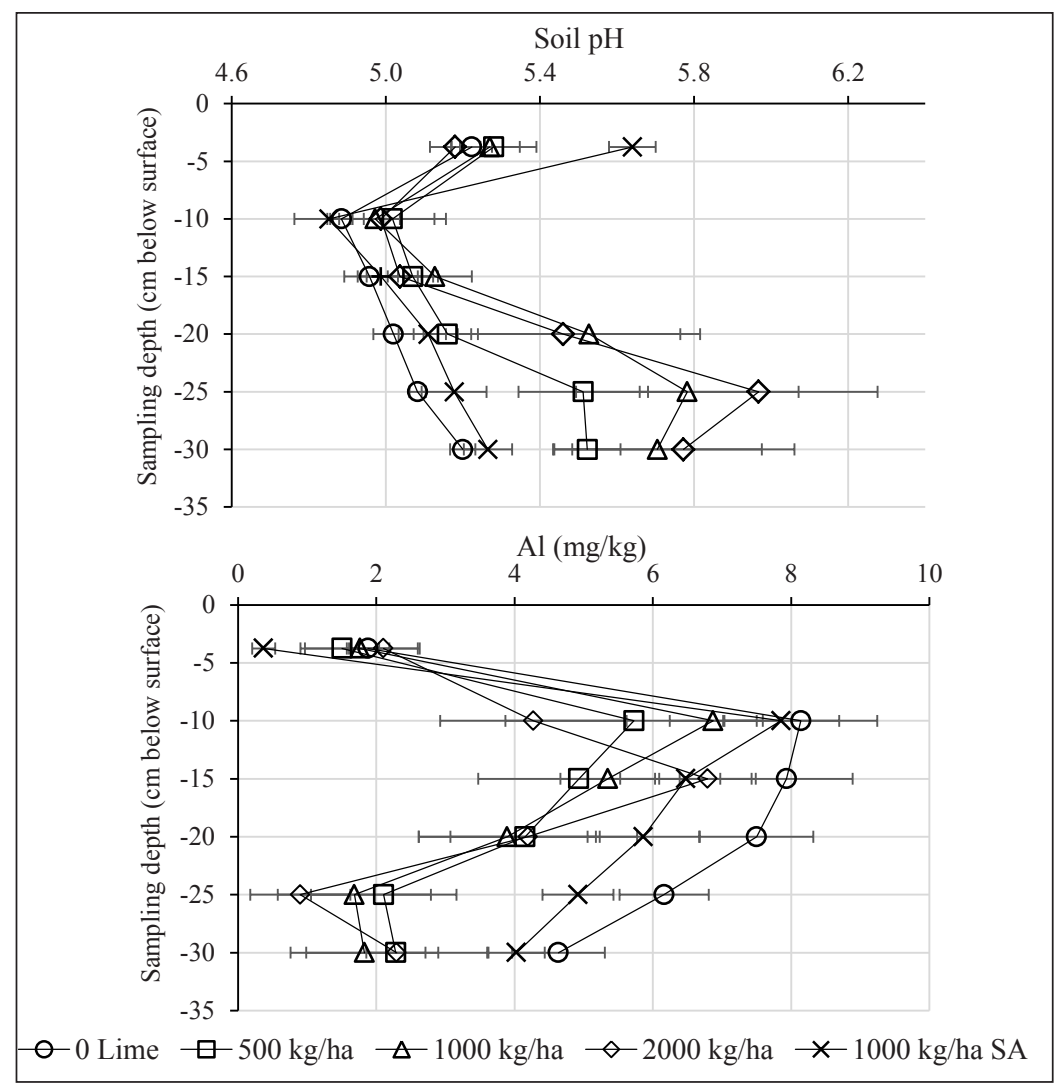

Figure 3 The cumulative effects of lime treatments on soil pH and Al at depth, January 2018.

\section{Statistical analysis}

Before the application of the fertiliser treatment herbage yield and root biomass for individual species, soil $\mathrm{pH}$ and $\mathrm{Al}$ level were all analysed by one-way ANOVA followed by a Fishers LSD test using Genstat 16. Following the fertiliser application herbage yield was analysed by two-way ANOVA with lime treatment as main plots and fertiliser treatment as subplots, 
followed by a Fishers LSD test for each plant species. Any effects of the fertiliser treatment on root biomass or soil $\mathrm{pH}$ and $\mathrm{Al}$ were not considered when doing the trench sampling. Following the two rounds of trench sampling the $\mathrm{Al}$ concentrations in the lucerne plots of Block 2 were consistently $<0.7 \mathrm{mg} / \mathrm{kg}$ at each depth and therefore not consistent with the high $\mathrm{Al}(>3 \mathrm{mg} / \mathrm{kg})$ in the other blocks. This highlights the variability of the Mackenzie soil across the landscape, so all plant yield, root biomass and soil analysis results from this block have been excluded from the results.

\section{Results}

\section{Soil pH and Al level}

At the December 2016 soil core sampling Al concentration decreased exponentially as $\mathrm{pH}$ increased at $20 \mathrm{~cm}$ depth (Figure 2). For the deep-placed lime treatments there was a wide range in $\mathrm{pH}$ and $\mathrm{Al}$ within treatments and $\mathrm{Al}$ toxicity was only alleviated at certain points within each of the $1 \mathrm{~m}$ sampling transects. This indicated that there was little lateral distribution of the pelleted lime from the delivery ports of the machine at this depth. Undissolved lime pellets were observed in the soil.

At the $20 \mathrm{~cm}$ sampling depth the highest levels of Al $(>14 \mathrm{mg} / \mathrm{kg})$ occurred at $\mathrm{pH} \leq 5.2$ in the control $(0 \mathrm{~kg} /$ ha) treatment. By contrast, at $\mathrm{pH} \geq 5.65 \mathrm{Al}$ was reduced to below the $3.0 \mathrm{mg} / \mathrm{kg}$ toxicity threshold by the deep application of lime. The $2000 \mathrm{~kg} / \mathrm{ha}$ deep-placed lime treatment had the most individual sampling points with $\mathrm{Al}$ below the $3.0 \mathrm{mg} / \mathrm{kg}$ toxicity threshold and, overall, $\mathrm{Al}$ was reduced by each of the deep-placed lime treatments compared with the control $(\mathrm{P}<0.01)$.

At increased sampling depths in January 2018 the greatest effect of the deep-placed lime occurred below $20 \mathrm{~cm}$ (Figure 3).

The deep placement of lime, irrespective of application rate, was successful at increasing $(\mathrm{P}<0.05)$ soil $\mathrm{pH}$ and reducing $(\mathrm{P}<0.001) \mathrm{Al}$ to below the toxicity threshold $(3 \mathrm{mg} / \mathrm{kg})$ at depths of 25 and $30 \mathrm{~cm}$. At

Table 2 DM yield/ha at Omarama Station in the second and third years of the experiment.

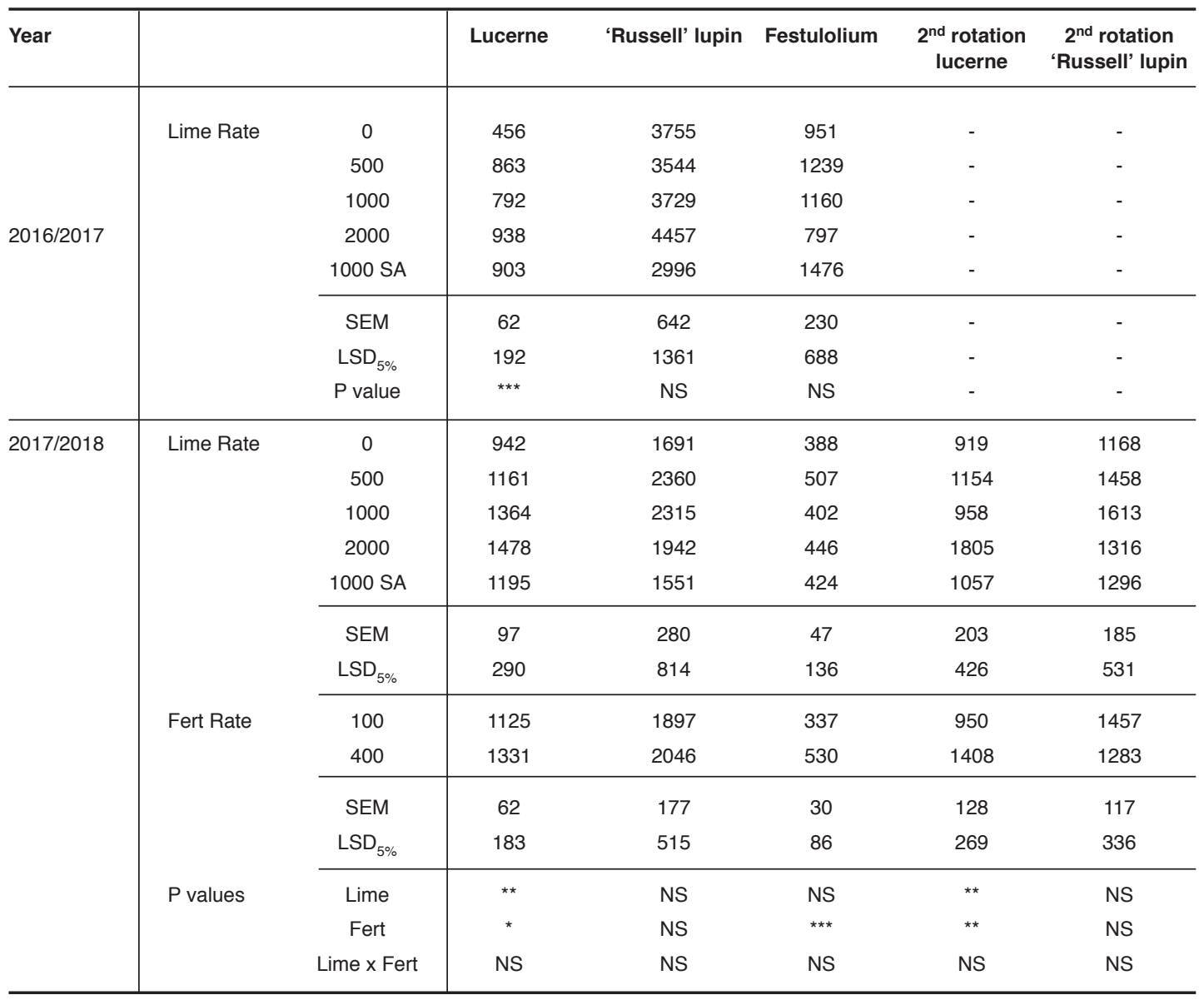


depths of less than $25 \mathrm{~cm}$ the deep-placed lime had no effect on soil $\mathrm{pH}$ and $\mathrm{Al}$ compared with the control. The $500 \mathrm{~kg} / \mathrm{ha}$ deep-placed lime application rate was sufficient to successfully reduce soil Al to below the toxicity threshold, but was not as effective at increasing soil $\mathrm{pH}$ as the two higher application rates. The 1000 $\mathrm{kg} / \mathrm{ha}$ surface- applied (SA) lime treatment increased soil $\mathrm{pH}(\mathrm{P}<0.001)$ and reduced $\mathrm{Al}(\mathrm{P}<0.001)$ in the top $7.5 \mathrm{~cm}$ of the soil profile, but had no effect below this depth.

\section{Herbage dry matter yield}

Dry matter (DM) yield for the lucerne and 'Russell' lupins was $<1000 \mathrm{~kg} / \mathrm{ha}$ in the establishment year and there was no effects of the lime treatments $(\mathrm{P}>0.05)$. The ryecorn yielded the greatest at just over $2000 \mathrm{~kg} /$ ha, irrespective of lime treatment.

The application of lime, both deep-placed and surface-applied, irrespective of application rate, increased the yield of lucerne over that of the control in $2016 / 2017$ and $2017 / 2018$. The $2000 \mathrm{~kg} / \mathrm{ha}$ application rate had the greatest effect on lucerne yield, this was the only treatment in the second rotation lucerne to cause an increase in yield in 2017/2018. The $400 \mathrm{~kg} / \mathrm{ha}$ fertiliser also increased the yield of lucerne and festulolium in 2017/2018 but the yields of both were low. Festulolium yield decreased year on year to the point the plants were mostly dead by April 2018.

The yield of the 'Russell' lupins exceeded that of the lucerne and festulolium in 2016/2017 and was not affected by lime or fertiliser application. By 2017/2018 the yield of the lucerne began to approach that of the 'Russell' lupins. This can be attributed to the continued establishment of the lucerne and a reduction in 'Russell' lupin population from $41.7 \pm 6.4$ plants $/ \mathrm{m}^{2}$ at the beginning of the experiment to an average of just 4.6 \pm 0.7 plants $/ \mathrm{m}^{2}$ by April 2018. The ryecorn breakin crop had no effect on second rotation lucerne and 'Russell' lupin yield.

\section{Root biomass}

Plant root biomass to a depth of $30 \mathrm{~cm}$ was not affected by lime in either December $2016(\mathrm{P}=0.97)$ or January $2018(\mathrm{P}=0.86)$. The average lucerne root biomass across all lime treatments increased from $1185 \pm 280$ $\mathrm{kg} / \mathrm{ha}$ in December 2016 to $1750 \pm 212 \mathrm{~kg} / \mathrm{ha}$ in January 2018. For the 'Russell' lupins it increased from $2630 \pm 937 \mathrm{~kg} / \mathrm{ha}$ in December 2016 to $6050 \pm 1855 \mathrm{~kg} /$ ha in January 2018. Despite there being no differences in total root biomass more laterally growing lucerne roots were observed in the control $(0 \mathrm{~kg} / \mathrm{ha}$ lime $)$ and surface applied lime plots than in the deep-placed limed plots. Lime treatments had no effect on the degree of branching $(\mathrm{P}=0.55)$ and plant nodulation $(\mathrm{P}=0.91)$ of both the lucerne and 'Russell' lupins at the January
2018 sampling. The level of branching in both the lucerne and 'Russell' lupins was $2.6 \pm 0.22$ and $2.7 \pm 0.37$ across all lime treatments, respectively. For nodulation the lucerne scored $1.1 \pm 0.16$ across all lime treatments compared to the 'Russell' lupins at 3.8 \pm 0.21 .

\section{Discussion}

The objective of the experiment was to determine if subsoil acidity and Al toxicity at Omarama Station could be reduced with deep lime placement technology. This was successfully achieved at a depth of $25-30 \mathrm{~cm}$ (Figure 3) with the lime delivered from the lower port of the machine. However, the lime delivered from the upper port $(5-10 \mathrm{~cm}$ below the soil surface) was not effective at reducing acidity and $\mathrm{Al}$ toxicity above 25 $\mathrm{cm}$. This is the likely limitation to the growth of the lucerne which will have been impeded by the $\mathrm{Al}$ in the intermediate soil layer, and this will have contributed to it failing to successfully nodulate (Berenji et al. 2017). The lower delivery port injects lime directly downwards into the void behind the foot of the ripper tine whereas the upper port is angled back slightly, so may have been more effective if it were angled for straight down delivery. Other possible solutions for increasing the effectiveness of the machine above $25 \mathrm{~cm}$ could include adjusting the application depths of the two delivery ports, or adding more delivery ports to the machine. A similar machine built by Nelson et al. (2012) had four delivery ports behind each ripper tine and the machine built by Farina \& Channon (1988) had six. For further development and commercialisation, adding more ports would seem an obvious modification because where the lime was successfully placed at depth, the Al toxicity was alleviated

When considering the lateral distribution of the deepplaced lime the machine created bands of soil where $\mathrm{pH}$ was increased and $\mathrm{Al}$ reduced, but between these bands the soil was not effectively limed (Figure 2). Correcting soil $\mathrm{pH}$ and eliminating $\mathrm{Al}$ toxicity in bands down the profile behind the ripper, will allow lucerne roots to grow down them and access more soil water, but is likely to prevent the plants from extracting nutrients from the unlimed soil between the bands creating greater inter-plant competition (Farina \& Channon 1988). This was evident in some plots where greater lucerne growth was visible in strips across the plots. To reduce this issue the spacing between the ripper tines could be narrowed or multiple passes of the machine through the soil made.

Despite the poor cumulative effect of the deepplaced lime at reducing $\mathrm{Al}$ above $25 \mathrm{~cm}$ depth, the yield of lucerne was significantly increased over that of the control treatment in both 2016/2017 and 2017/2018. Root biomass showed no difference between the lime treatments. However, the control and surface-applied 
lime treatment plots contained a greater proportion of laterally growing roots than the deep-placed lime treated plots which had deeper growing roots. Had the deep-placed lime been more effective in the top $20 \mathrm{~cm}$ of the profile the yield and nodulation of the lucerne could have been greater. Implementing the modifications and application methods suggested above could improve the efficiency and economic viability of using the machine to develop stands of lucerne in hill and high-country environments. It is likely that directly injecting lime would be more successful in areas with higher rainfall, where lime pellets dissolve more rapidly.

The yield of the festulolium decreased as the experiment went on, probably due to nitrogen deficiency and its shallow rooting system. This highlighted the importance of growing deep rooting, nitrogen fixing legumes in these dryland environments. Overall, the 'Russell' lupins were the most successful plant at the site. It is likely the lupin density decreased due to the plants being unable to withstand intense mowing of the plots following herbage yield measurements (Moot \& Pollock 2014). In a lax grazing system the lupin plant population would be expected to self-govern and higher yields could have been achieved at the site if the plots had not been mown. Unlike lucerne and festulolium the 'Russell' lupins were not affected by either the lime or the fertiliser treatments and were able to successfully nodulate in unlimed soil, highlighting their potential for use in acid, low fertility South Island hill and highcountry soils.

\section{ACKNOWLEDGEMENTS}

The authors acknowledge Richard and Annabelle Subtil of Omarama Station, Geoff Gray for building the lime machine, CP Lime Solutions for providing the Optimise ${ }^{\circledR}$ lime, Dave Jack, Dr Keith Pollock, Malcolm Smith, Travis Ryan-Salter, Sarah Graham and all other helpers with field work, Dharini Paramashivam and Lynne Clucas for sample analysis, and Farmgard for the ripper tines. Funding was provided by the Fertiliser Association of New Zealand, AGMARDT, Callaghan Innovation, the Don Hulston Foundation Scholarship, and $\mathrm{Mr}$ Roland Stead.

\section{REFERENCES}

Anderson, D.; Anderson, L.; Moot, D.J.; Ogle, G.I. 2014. Intergrating lucerne (Medicago sativa L.) into a high country merino system. Proceedings of the New Zealand Grassland Association 76: 29-34.

Berenji, S.; Moot, D.J.; Moir, J.L.; Ridgway, H.; Rafat, A. 2017. Dry matter yield, root traits, and nodule occupancy of lucerne and Caucasian clover when grown in acidic soil with high aluminium concentrations. Plant and Soil 416: 227-241.
Blakemore, L.C.; Searle, P.L.; Daly, B.K. 1987. Methods of chemical analysis of soils. Lower Hutt, New Zealand Soil Science Bureau, Volume 80.

Coventry, D.R. 1991. The injection of slurries of lime, associated with deep tillage, to increase wheat production on soils with subsoil acidity. pp. 437-445. In: (Eds.) Wright, R.J.; Baligar, V.C.; Murrmann, R.P. Plant-soil interactions at low $\mathrm{pH}$. Proceedings of the 2nd international symposium on plant-soil interactions at low $\mathrm{pH}$. Springer Netherlands.

CP Lime Solutions Ltd 2015. Optimise pelleted lime-based fertilisers. http://www.optimise.net.nz/ optimise.html

Edmeades, D.C.; Smart, C.E.; Wheeler, D.M. 1983. Aluminium toxicity in New Zealnd soils: preliminary results on the development of diagnostic criteria. New Zealand Journal of Agricultural Research 26: 493-501.

Farina, M.P.W.; Channon, P. 1988. Acid-subsoil amelioration: I. A comparison of several mechanical procedures. Soil Science Society of America Journal 52: 169-175.

Foy, C.D.; Chaney, R.L.; White, M.C. 1978. The physiology of metal toxicity in plants. Annual Review of Plant Physiology 29: 511-566.

Kirchhof, G.; Jayawardane, N.S.; Blackwell, J.; Murray, E. 1995. Lime-slotting technique to ameliorate subsoil acidity in a clay soil. I. Effects on soil $\mathrm{pH}$ and physical characteristics. Australian Journal of Soil Research 33: 425-441.

Moir, J.L.; Moot, D.J. 2014. Medium-term soil pH and exchangeable aluminium response to liming at three high country locations. Proceedings of the New Zealand Grassland Association 76: 41-45.

Moir, J.L.; Jordan, P.; Moot, D.J.; Lucas, R.J. 2016. Phosphorus response and optimum $\mathrm{pH}$ ranges of twelve pasture legumes grown in an acid upland New Zealand soil under glasshouse conditions. Journal of Soil Science and Plant Nutrition 16: 438-460.

Moot, D.J.; Pollock, K.M. 2014. Perennial lupin establishment and yield when sown at five different rates at Glenmore Station, Lake Tekapo. Proceedings of the New Zealand Grassland Association 76: 5360 .,

Nelson, K.; Scharf, P.; Dudenhoeffer, C.; Motavalli, P. 2012. Benefits of lime placement on grain yield response and remediation of acid subsoils. Progress report to the Missouri Agricultural Experiment Station, College of Agriculture, Food and Natural Resources, University of Missouri.

S-Map. 2015. Soil Report: Mackenzief shallow loam. Landcare Research New Zealand Ltd 2011-2015.

Scott, D. 1989. Perennial or Russell Lupin: A potential high country pasture legume. Proceedings of the New Zealand Grassland Association 50: 203-207. 
Scott, D. 2003. Dryland legumes: perspectives and problems. Legumes for Dryland Pastures: Grassland Research and Practice Series 11: 27-36.

Watkinson, J.H.; Kear, M.J. 1996. Sulfate and mineralisable organic sulphur in pastoral soils of New Zealand. Part II. A soil test for mineralisable organic sulphur. Australian Journal of Soil Research
34: 405-412.

Whitley, A.E.; Moir, J.L.; Almond, P.C.; Moot, D.J. 2016. Soil $\mathrm{pH}$ and exchangeable aluminium in contrasting New Zealand high and hill country soils. Hill Country Symposium. Grassland Research and Practice Series 16: 166-172. 
